\title{
Evaluation of the synergistic potential of vancomycin combined with other antimicrobial agents against methicillin-resistant Staphylococcus aureus and coagulase-negative Staphylococcus spp strains
}

\author{
Lívia Viganor da Silva', Manuela Tedesco Araújo', \\ Kátia Regina Netto dos Santos², Ana Paula Ferreira Nunes ${ }^{1 /+}$
}

\author{
'Laboratório de Resistência Bacteriana, Departamento de Patologia, Universidade Federal do Espírito Santo, Vitória, ES, Brasil \\ ${ }^{2}$ Laboratório de Infecção Hospitalar, Departamento de Microbiologia Médica, Universidade Federal do Rio de Janeiro, Rio de Janeiro, RJ, Brasil
}

Methicillin-resistant Staphylococcus aureus (MRSA) and coagulase-negative Staphylococcus spp (CNS) are the most common pathogens that cause serious long term infections in patients. Despite the existence of new antimicrobial agents, such as linezolid, vancomycin (VAN) remains the standard therapy for the treatment of infections caused by these multidrug-resistant strains. However, the use of VAN has been associated with a high frequency of therapeutic failures in some clinical scenarios, mainly with decreasing concentration of VAN. This work aims to evaluate the synergic potential of VAN plus sulfamethoxazole/trimethoprim (SXT), VAN plus rifampin (RIF) and VAN plus imipenem (IPM) in sub-minimum inhibitory concentrations against 22 clinical strains of MRSA and CNS. The checkerboard method showed synergism of VAN/RIF and VAN/SXT against two and three of the 22 strains, respectively. The combination of VAN with IPM showed synergistic effects against 21 out of 22 strains by the E-test method. Four strains were analyzed by the time-kill curve method and synergistic activity was observed with VAN/SXT, VAN/RIF and especially VAN/IPM in sub-inhibitory concentrations. It would be interesting to determine if synergy occurs in vivo. Evidence of in vivo synergy could lead to a reduction of the standard VAN dosage or treatment time.

Key words: MRSA - MRCNS - vancomycin - synergism - checkerboard - time-kill curve

Prolonged hospitalization can make patients susceptible to serious bacterial infections caused primarily by multi-resistant microorganisms, such as Staphylococcus aureus and coagulase-negative Staphylococcus spp (CNS) [methicillin-resistant CNS (MRCNS)]. Methicillin resistance of these organisms have reached $60 \%$ and $90 \%$, respectively (Hidron et al. 2008). Methicillin resistance is only observed among Staphylococcus species and is related to $\beta$-lactam resistance. As a consequence, vancomycin (VAN) has become widely used for treatment. However, VAN has recently been associated with high rates of treatment failure and recurrent infection due to a setting of decreased VAN concentration, e.g., in patients requiring haemodialysis (Pallotta \& Manley 2008) and if the methicillin-resistant $S$. aureus (MRSA) strain has a VAN minimum inhibitory concentration (MIC) $\geq 1 \mathrm{mg} / \mathrm{L}$ (Rybak et al. 2009). Administration of high doses of VAN has been used to treat bone, joint, central nervous system and pulmonary infections with the goal of reducing therapeutic failures (Dehority 2010). However, Staphylococcus spp has developed resistance to low VAN levels and, recently, a VAN-resistant $S$. aureus was isolated in the USA that had obtained the vanA gene from Enterococcus spp (Sievert et al. 2008).

Financial support: FAPES, FACITEC, CAPES

+ Corresponding author: anastron@gmail.com

Received 24 May 2010

Accepted 27 October 2010
New antimicrobial agents to replace VAN have been launched in the market, but are expensive and have limited sales availability, especially in developing countries (Christoffersen 2006). However, some studies that used different techniques have indicated that variable drug combinations can have synergistic effects against staphylococcal isolates (Rochon-Edouard et al. 2000, Alou et al. 2004, Rand \& Houck 2004, Kobayashi 2005, Miranda-Novales et al. 2006). In this study we evaluated the synergistic potential of the combinations VAN and sulfamethoxazole/ trimethoprim (SXT), VAN and rifampin (RIF) and VAN with imipenem (IPM) by checkerboard, E-test and timekill curve methods against MRSA and MRCNS isolates.

\section{MATERIALS AND METHODS}

Bacterial strains - Twenty two clinical strains of MRSA (11 isolates) and MRCNS (11 isolates) isolated from different sites of infection from inpatients in a hospital of Vitória, Espírito Santo, Brazil, were identified by the Microscan WalkAway and confirmed as methicillinresistant by detection of the mecA gene by polymerase chain reaction (Schuenck et al. 2008) (Table I). S. aureus ATCC 29213 was used as a sensitive control strain (methicillin sensitive $S$. aureus) and ATCC 33591 as a resistant control strain (MRSA). The MICs of RIF, SXT and VAN were determined by the broth microdilution method in accordance with standard guidelines (CLSI 2009).

Screening antimicrobial combinations - The synergism, additivity, indifference and antagonism of the antimicrobial combinations VAN + SXT and VAN + RIF were initially screened on the 22 staphylococcal strains by the checkerboard method. For the VAN + IPM com- 
TABLE I

Minimum inhibitory concentration (MIC) and fractional inhibitory concentration (FIC) index results of vancomycin (VAN) plus sulfamethoxazole/trimethoprim (SXT) and VAN plus rifampin (RIF) combinations against 11 methicillin-resistant Staphylococcus aureus (MRSA) and 11 methicillin-resistant coagulase-negative $S$. aureus strains using the checkerboard method

\begin{tabular}{|c|c|c|c|c|c|c|}
\hline MRSA strain & $\begin{array}{c}\mathrm{MIC} \\
(\mu \mathrm{g} / \mathrm{mL})\end{array}$ & $\begin{array}{l}\text { MIC }(\mu \mathrm{g} / \mathrm{mL}) \\
\mathrm{VAN}+\mathrm{SXT}\end{array}$ & FIC index & $\begin{array}{c}\mathrm{MIC} \\
(\mu \mathrm{g} / \mathrm{mL})\end{array}$ & $\begin{array}{c}\mathrm{MIC}(\mu \mathrm{g} / \mathrm{mL}) \\
\mathrm{VAN}+\mathrm{RIF}\end{array}$ & FIC index \\
\hline 146 & $\begin{array}{c}\mathrm{VAN}=1.0 \\
\mathrm{SXT}=19 / 1.0\end{array}$ & $0.25+4.75 / 0.25$ & $0.5(\mathrm{Sg})$ & $\begin{array}{l}\mathrm{VAN}=1.0 \\
\mathrm{RIF}=4.0\end{array}$ & $0.06+2.0$ & $0.56(\mathrm{Ad})$ \\
\hline 168 & $\begin{array}{c}\mathrm{VAN}=1.0 \\
\mathrm{SXT}=19 / 1.0\end{array}$ & $0.5+4.75 / 0.25$ & 0.75 (Ad) & $\begin{array}{l}\mathrm{VAN}=1.0 \\
\mathrm{RIF}=4.0\end{array}$ & $0.13+2.0$ & $0.63(\mathrm{Ad})$ \\
\hline 183 & $\begin{array}{c}\mathrm{VAN}=1.0 \\
\mathrm{SXT}=19 / 1.0\end{array}$ & $0.06+19 / 1.0$ & $1.06(\mathrm{Ad})$ & $\begin{array}{l}\mathrm{VAN}=1.0 \\
\mathrm{RIF}=4.0\end{array}$ & $0.06+2.0$ & $0.56(\mathrm{Ad})$ \\
\hline 191 & $\begin{array}{c}\mathrm{VAN}=1.0 \\
\mathrm{SXT}=2.38 / 0.12\end{array}$ & $0.06+1.19 / 0.06$ & $0.56(\mathrm{Ad})$ & $\begin{array}{l}\mathrm{VAN}=1.0 \\
\mathrm{RIF}=4.0\end{array}$ & $0.06+2.0$ & $0.56(\mathrm{Ad})$ \\
\hline 192 & $\begin{array}{c}\mathrm{VAN}=2.0 \\
\mathrm{SXT}=9.5 / 0.5\end{array}$ & $0.25+1.19 / 0.06$ & $0.25(\mathrm{Sg})$ & $\begin{array}{l}\mathrm{VAN}=1.0 \\
\mathrm{RIF}=4.0\end{array}$ & $0.06+2.0$ & 0.56 (Ad) \\
\hline 225 & $\begin{array}{c}\mathrm{VAN}=1.0 \\
\mathrm{SXT}=2.38 / 0.12\end{array}$ & $0.12+1.19 / 0.06$ & $0.63(\mathrm{Ad})$ & $\begin{array}{l}\mathrm{VAN}=1.0 \\
\mathrm{RIF}=2.0\end{array}$ & $0.5+1.0$ & $1.0(\mathrm{Ad})$ \\
\hline 226 & $\begin{array}{c}\mathrm{VAN}=1.0 \\
\mathrm{SXT}=2.38 / 0.12\end{array}$ & $0.06+1.19 / 0.06$ & $0.56(\mathrm{Ad})$ & $\begin{array}{l}\mathrm{VAN}=1.0 \\
\mathrm{RIF}=2.0\end{array}$ & $0.25+1.0$ & 0.75 (Ad) \\
\hline 227 & $\begin{array}{c}\mathrm{VAN}=1.0 \\
\mathrm{SXT}=2.38 / 0.12\end{array}$ & $0.06+1.19 / 0.06$ & $0.56(\mathrm{Ad})$ & $\begin{array}{l}\mathrm{VAN}=2.0 \\
\mathrm{RIF}=2.0\end{array}$ & $1.0+1.0$ & $1.0(\mathrm{Ad})$ \\
\hline 230 & $\begin{array}{c}\mathrm{VAN}=1.0 \\
\mathrm{SXT}=2.38 / 0.12\end{array}$ & $0.06+1.19 / 0.06$ & $0.56(\mathrm{Ad})$ & $\begin{array}{l}\mathrm{VAN}=2.0 \\
\mathrm{RIF}=2.0\end{array}$ & $0.06+2.0$ & $1.0(\mathrm{Ad})$ \\
\hline 232 & $\begin{array}{c}\mathrm{VAN}=2.0 \\
\mathrm{SXT}=2.38 / 0.12\end{array}$ & $0.5+0.6 / 0.03$ & $0.50(\mathrm{Sg})$ & $\begin{array}{l}\mathrm{VAN}=2.0 \\
\mathrm{RIF}=4.0\end{array}$ & $1.0+2.0$ & $1.0(\mathrm{Ad})$ \\
\hline 241 & $\begin{array}{c}\mathrm{VAN}=2.0 \\
\mathrm{SXT}=1.19 / 0.06\end{array}$ & $0.06+1.19 / 0.06$ & $1.0(\mathrm{Ad})$ & $\begin{array}{l}\mathrm{VAN}=2.0 \\
\mathrm{RIF}=4.0\end{array}$ & $0.13+2.0$ & $0.56(\mathrm{Ad})$ \\
\hline 155 & $\begin{array}{c}\mathrm{VAN}=2.0 \\
\mathrm{SXT}=152 / 8.0\end{array}$ & $0.06+76 / 4.0$ & $0.50(\mathrm{Sg})$ & $\begin{array}{l}\mathrm{VAN}=2.0 \\
\mathrm{RIF}=1024\end{array}$ & $0.06+512$ & $0.50(\mathrm{Sg})$ \\
\hline 175 & $\begin{array}{c}\mathrm{VAN}=2.0 \\
\mathrm{SXT}=152 / 8.0\end{array}$ & $1.0+76 / 4.0$ & $1.0(\mathrm{Ad})$ & $\begin{array}{l}\mathrm{VAN}=2.0 \\
\mathrm{RIF}>1024\end{array}$ & $1.0+256$ & 0.75 (Ad) \\
\hline 186 & $\begin{array}{c}\mathrm{VAN}=2.0 \\
\mathrm{SXT}=76 / 4.0\end{array}$ & $1.0+38 / 2.0$ & 1.0 (Ad) & $\begin{array}{l}V A N=2.0 \\
\text { RIF }>1024\end{array}$ & $1.0+1024$ & $1.5(\mathrm{Ad})$ \\
\hline 253 & $\begin{array}{c}\mathrm{VAN}=2.0 \\
\mathrm{SXT}=76 / 4.0\end{array}$ & $1.0+38 / 2.0$ & $1.0(\mathrm{Ad})$ & $\begin{array}{c}\mathrm{VAN}=2.0 \\
\mathrm{RIF}=0.004\end{array}$ & $1.0+0.001$ & $0.75(\mathrm{Ad})$ \\
\hline 262 & $\begin{array}{c}\mathrm{VAN}=2.0 \\
\mathrm{SXT}=608 / 32\end{array}$ & $1.0+304 / 16$ & $1.0(\mathrm{Ad})$ & $\begin{array}{l}\mathrm{VAN}=2.0 \\
\mathrm{RIF}=8.0\end{array}$ & $0.125+4$ & $0.56(\mathrm{Ad})$ \\
\hline 159 & $\begin{array}{c}\mathrm{VAN}=2.0 \\
\mathrm{SXT}=1.19 / 0.06\end{array}$ & $0.06+1.19 / 0.06$ & $1.0(\mathrm{Ad})$ & $\begin{array}{l}\mathrm{VAN}=2.0 \\
\mathrm{RIF}>256\end{array}$ & $1.0+64$ & $0.75(\mathrm{Ad})$ \\
\hline 263 & $\begin{array}{c}\mathrm{VAN}=2.0 \\
\mathrm{SXT}=152 / 8.0\end{array}$ & $1.0+38 / 2.0$ & 0.75 (Ad) & $\begin{array}{l}\mathrm{VAN}=2.0 \\
\mathrm{RIF}=0.002\end{array}$ & $0.06+0.002$ & $1.0(\mathrm{Ad})$ \\
\hline 167 & $\begin{array}{c}\mathrm{VAN}=2.0 \\
\mathrm{SXT}=2432 / 128\end{array}$ & $0.12+1216 / 64$ & $0.56(\mathrm{Ad})$ & $\begin{array}{c}\mathrm{VAN}=2.0 \\
\mathrm{RIF}=0.004\end{array}$ & $0.06+0.004$ & $1.0(\mathrm{Ad})$ \\
\hline 223 & $\begin{array}{c}\mathrm{VAN}=1.0 \\
\mathrm{SXT}=38 / 2.0\end{array}$ & $0.06+38 / 2.0$ & 1.1 (Ad) & $\begin{array}{l}\mathrm{VAN}=2.0 \\
\mathrm{RIF}>1024\end{array}$ & $1.0+256$ & $0.75(\mathrm{Ad})$ \\
\hline 189 & $\begin{array}{c}\mathrm{VAN}=2.0 \\
\mathrm{SXT}=304 / 16\end{array}$ & $1.0+76 / 4.0$ & 0.75 (Ad) & $\begin{array}{c}\mathrm{VAN}=2.0 \\
\mathrm{RIF}=0.004\end{array}$ & $1.0+0.002$ & $1.0(\mathrm{Ad})$ \\
\hline 193 & $\begin{array}{c}\mathrm{VAN}=2.0 \\
\mathrm{SXT}=152 / 8.0\end{array}$ & $1.0+19 / 1.0$ & $0.63(\mathrm{Ad})$ & $\begin{array}{l}\mathrm{VAN}=2.0 \\
\mathrm{RIF}=0.015\end{array}$ & $0.5+0.002$ & $0.38(\mathrm{Sg})$ \\
\hline
\end{tabular}

FIC index: $\leq 0.5$ : synergism (Sg); 0.5-<2.0: additive effect (Ad); $\geq 2.0-<4.0$ : indifference; $\geq 4.0$ : antagonism (Lorian 2005).

bination, the screening was done by the E-test method due to the scarcity of IPM powder available, which was reserved for the time-kill curve method.
Checkerboard method - This method was carried out using 96-well microplates containing cation-supplemented Mueller-Hinton Broth (ca-MHB) (Difco) with VAN 
(Sigma) concentrations ranging from 1/16-4 $\times$ MIC in the columns and SXT (Sigma) or RIF (Sigma) concentrations ranging from 1/8-2 $\times$ MIC along the rows, then combined with each other on the plate in a checkerboard style. The bacterial inoculum was $5 \times 10^{5}$ colony-forming unit $(\mathrm{CFU}) / \mathrm{mL} /$ well. The microplates were incubated for $24 \mathrm{~h}$ at $37^{\circ} \mathrm{C}$ (Jacqueline et al. 2005). The fractional inhibitory concentration (FIC) index was calculated as follows: drug A FIC (drug A MIC combined/drug A MIC alone) + drug B FIC (drug B MIC combined/drug B MIC alone). Synergism was defined as FIC index $\leq 0.5$; additivity FIC index $>0.5-<2$; indifference FIC index $\geq 2-<4$ and antagonism FIC index $\geq 4$ (Lorian 2005). The strains that had MIC $>$ $32 \mu \mathrm{g} / \mathrm{mL}$ and MIC $>1024 \mu \mathrm{g} / \mathrm{mL}$ were considered to be MIC of $64 \mu \mathrm{g} / \mathrm{mL}$ and $2048 \mu \mathrm{g} / \mathrm{mL}$, respectively.

E-test method - E-test strips of IPM (AB Biodisk) were placed on plates containing Mueller-Hinton agar (Difco) with and without $0.5 \mu \mathrm{g} / \mathrm{mL}(1 / 2 \mathrm{MIC})$ of VAN and incubated at $37^{\circ} \mathrm{C}$ for $24 \mathrm{~h}$. The FIC for the antimicrobial combination was calculated from the MICs obtained in the plates with 1/2 MIC of VAN and without VAN (Lorian 2005). The strains that had MIC $>32 \mu \mathrm{g} / \mathrm{mL}$ was considered to be MIC of $64 \mu \mathrm{g} / \mathrm{mL}$ for the calculation of FIC.

Kinetics of antimicrobials combinations - The time-kill curve method was used to better analyze the synergistic effect of the antimicrobials combinations on the staphylococcal strains over time. The four strains (2 MRSA strains and 2 MRCNS strains) that had the best checkerboard and E-test results were selected for this method.

Time-kill curve method - Tubes containing ca-MHB and VAN, SXT, RIF and IPM (Merck Sharp \& Dhome) alone as well as in combinations (VAN + SXT; VAN + RIF; VAN + IPM) at sub-MIC concentrations according to MIC determined by the broth microdilution method (Table I) (CLSI 2009) were inoculated with a $10^{6} \mathrm{CFU} /$ $\mathrm{mL}$ bacterial suspension. A tube containing ca-MHB and bacteria only was used as the control. After $0,3,6,12$ and $24 \mathrm{~h}$ of incubation at $37^{\circ} \mathrm{C}$, an aliquot of each culture was serially diluted and spread onto MH agar plates (Jacqueline et al. 2005). This experiment was repeated with the reapplication of antimicrobials after $6 \mathrm{~h}$ of incubation. The criteria for classification as bacteriostatic or bactericidal effect, synergism or antagonism were assigned according to Lorian (2005) with modifications. Bacteriostatic and bactericidal effects were defined as a decrease of $<3 \log$ $\mathrm{CFU} / \mathrm{mL}$ and $\geq 3 \log \mathrm{CFU} / \mathrm{mL}$ after $24 \mathrm{~h}$ of incubation respectively, compared to the size of the initial inoculum. Synergism was defined as a decrease of $\geq 2 \log \mathrm{CFU} / \mathrm{mL}$ in test tubes with an antimicrobial combination compared to those with VAN alone. Antagonism was defined as an increase of $\geq 2 \log \mathrm{CFU} / \mathrm{mL}$ in test tubes with an antimicrobial combination compared to those with VAN alone.

\section{RESULTS}

The screening showed synergistic effects of the VAN + SXT combination against three MRSA strains: 146 (FIC index 0.5), 192 (FIC index 0.25) and 232 (FIC index 0.5) and one MRCNS strain, 155 (FIC index $0.5)$. The VAN + RIF combination showed synergistic

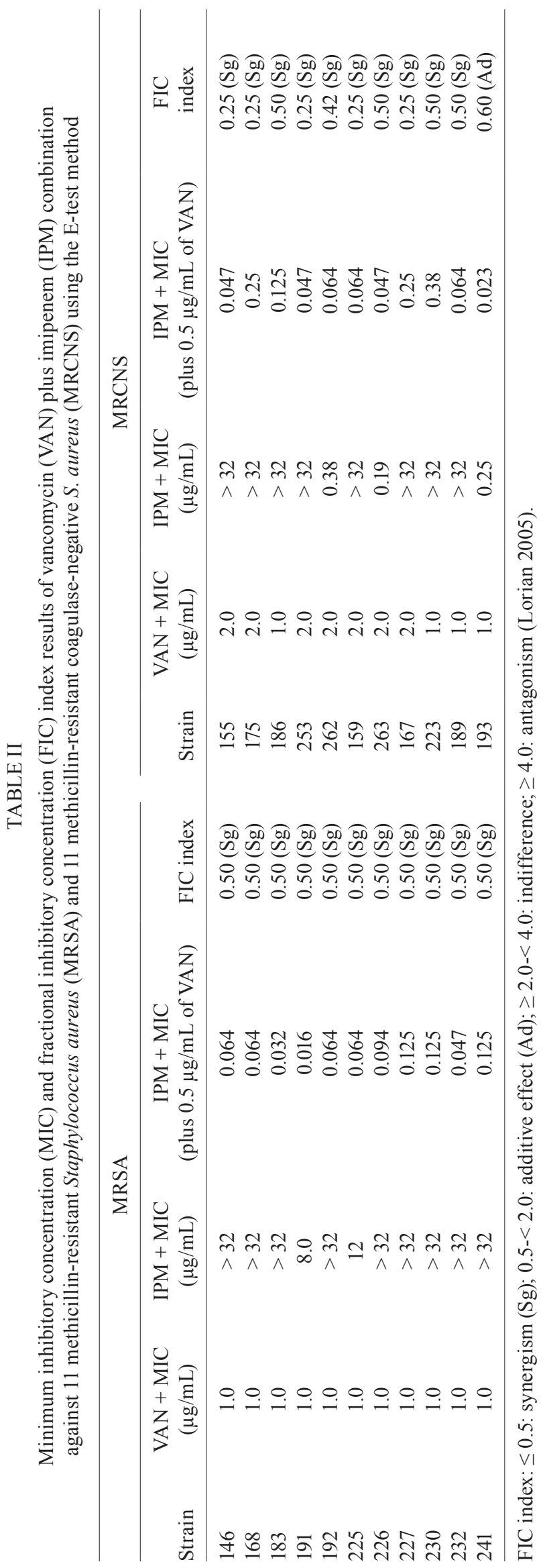


TABLE III

Log reduction of colony-forming unit (CFU)/mL of methicillin-resistant Staphylococcus aureus (MRSA) and methicillin-resistant coagulase-negative $S$. aureus (MRCNS) isolates using the time-kill curve method after $24 \mathrm{~h}$ of incubation at $37^{\circ} \mathrm{C}$ in different drug combinations in relation to sulfamethoxazole/trimethoprim (SXT), rifampin (RIF), imipenem (IPM) and vancomycin (VAN) alone

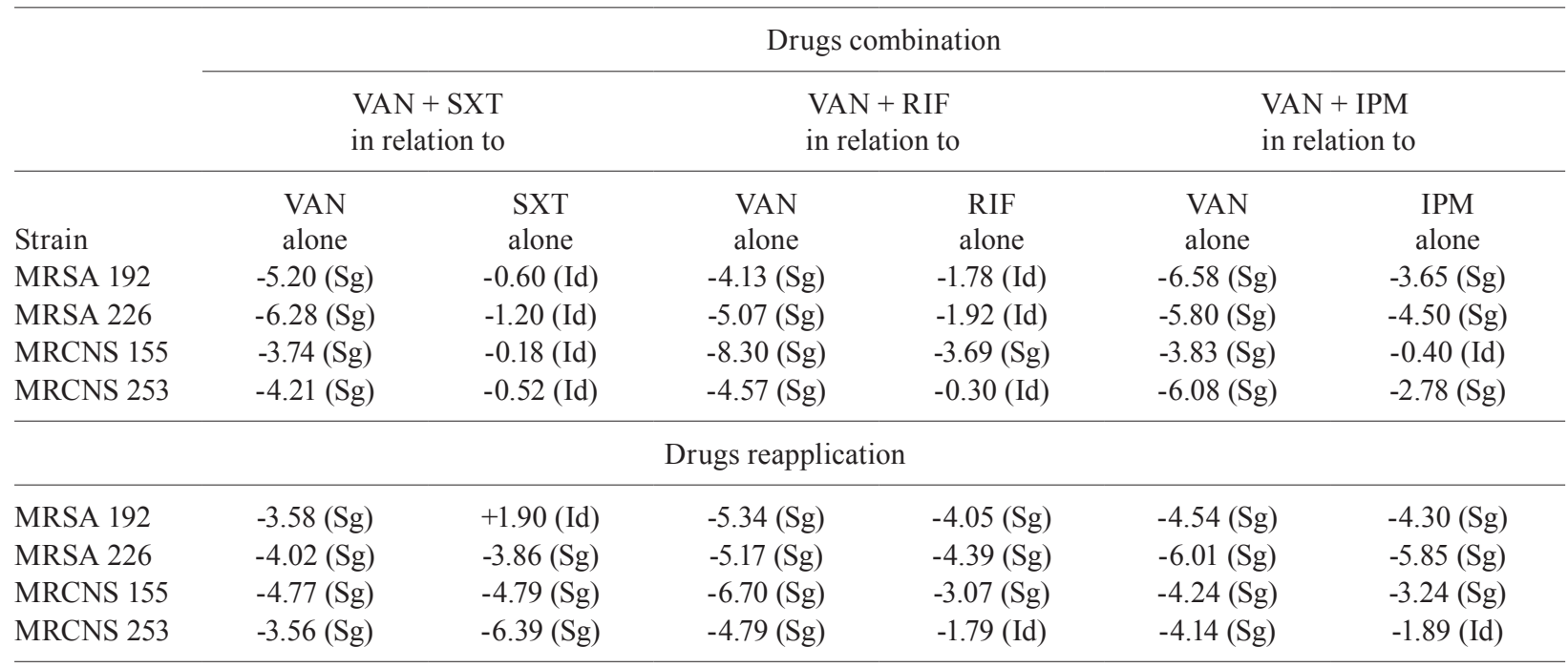

decrease $\geq 2 \log$ CFU/mL of strain in drugs combination related to more active drug alone: synergism (Sg); decrease $<2$ log CFU/ $\mathrm{mL}$ or increase $>2 \log \mathrm{CFU} / \mathrm{mL}$ of strain in drugs combination related to more active drug alone: indifference (Id); increase $\geq 2$ $\log \mathrm{CFU} / \mathrm{mL}$ of strain in drugs combination related to more active drug alone: antagonism (Lorian 2005).

effects against two MRCNS strains: 155 (FIC index 0.5 ) and 193 (FIC index 0.38). Both antimicrobial combinations showed additive effects for the remainder of the strains (Table I). By the E-test, VAN + IPM showed a synergistic FIC index of 0.5 against all MRSA and almost all MRCNS strains, except against MRCNS strain 193 (FIC index 0.6), for which the effect was additive (Table II).

The strains 192 and 226 MRSA and 155 and 253 MRCNS were selected for the time-kill curve method because they had the best results in synergistic and additive effects with the checkerboard and E-test methods. The VAN + SXT, VAN + RIF and VAN + IPM combinations demonstrated synergism within $24 \mathrm{~h}$ of incubation for all strains (Table III). Compared to VAN alone, no combination of antimicrobials had significant reduction on the rate of bacterial growth when reapplied after $6 \mathrm{~h}$ of incubation.

During the studies of kinetics of the MRSA strains, VAN and others antibiotics alone showed no effect, except for SXT, compared to the initial inoculum. However, the synergistic antimicrobial combinations of VAN at sub-inhibitory concentrations showed bacteriostatic effects for almost all strains. Moreover, after the antimicrobial reapplication, some of the synergistic antimicrobial combinations of VAN showed a bactericidal effect, while others continued to show a bacteriostatic effect (Table IV). The MRCNS, VAN and other antibiotics alone or in combination showed no effect. After antimicrobial reapplication, the antimicro- bial alone continued to not show any effect against the MRCNS strains. However, synergistic antimicrobial combinations of VAN at sub-inhibitory concentrations showed bactericidal and bacteriostatic effects against both strains (Table V).

\section{DISCUSSION}

The wide use of VAN for the treatment of severe infections caused by MRSA and MRCNS and its therapeutic failures have led to an increase in microbial resistance, relapse of infection incidence and worsening of patients' clinical conditions (Pallotta \& Manley 2008, Rybak et al. 2009, Dehority 2010, Hazlewood et al. 2010). Due to a lack of therapeutic options, some studies have focused on the combination of two or more antibiotics as an alternative treatment (Totsuka et al. 1999, Rochon-Edouard et al. 2000, Kobayashi 2005, Yamaoka 2007, Nguyen \& Graber 2010). Promising results in vitro and in vivo could lead to effective therapy along with a reduction of therapeutic doses, adverse effects and treatment duration.

Although most of our checkerboard results showed additive effects and synergistic effects on only six strains, antagonistic effects were not found. Furthermore, the additive and synergistic effects occurred particularly in sub-MIC concentrations of VAN $(\leq 0.5 \mu \mathrm{g} /$ $\mathrm{mL}), \operatorname{SXT}(\leq 4.75 / 0.25 \mu \mathrm{g} / \mathrm{mL})$ and $\operatorname{RIF}(\leq 1 \mu \mathrm{g} / \mathrm{mL})$ against most of the strains. In this regard, we cannot exclude the possibility that the additive effects may have been a result of the method's limitations, since the 


\section{TABLE IV}

Log reduction of colony-forming unit (CFU)/mL of methicillin-resistant Staphylococcus aureus isolates using the time-kill curve after incubation with sulfamethoxazole/trimethoprim (SXT), rifampin (RIF) and imipenem (IPM) alone and in combination with vancomycin (VAN) in relation to the initial inoculum after $24 \mathrm{~h}$ of incubation on $37^{\circ} \mathrm{C}$

\begin{tabular}{|c|c|c|c|c|c|c|c|c|}
\hline \multirow[b]{2}{*}{ Strain } & \multicolumn{8}{|c|}{$\log \mathrm{CFU} / \mathrm{mL}$} \\
\hline & Control & VAN & SXT & RIF & IPM & $\mathrm{VAN}+\mathrm{SXT}$ & VAN + RIF & VAN + IPM \\
\hline & +6.65 & +3.83(Ø) & $-0.9(b)$ & - & - & $-1.5(\mathrm{Sb})$ & - & - \\
\hline \multirow[t]{3}{*}{192} & +3.19 & +3.21(Ø) & - & $+0.77(\varnothing)$ & - & - & $-1.07(\mathrm{Sb})$ & - \\
\hline & +8.23 & +4.43(Ø) & - & - & $+1.85(\varnothing)$ & - & - & $-2.12(\mathrm{Sb})$ \\
\hline & +7.74 & +3.97 (Ø) & $-1.4(b)$ & - & - & $-2.4(\mathrm{Sb})$ & - & - \\
\hline \multirow[t]{4}{*}{226} & +1.21 & $+5.22(\varnothing)$ & - & +1.94 (Ø) & - & - & $+0.15(\mathrm{~S} \varnothing)$ & - \\
\hline & +8.4 & +2.90(Ø) & - & - & +1.50(Ø) & - & - & $-2.8(\mathrm{Sb})$ \\
\hline & \multicolumn{8}{|c|}{ Log CFU/mL (reapplication after $6 \mathrm{~h}$ of incubation) } \\
\hline & +8.47 & +1.83(Ø) & $-3.48(B)$ & - & - & $-1.68(\mathrm{Sb})$ & - & - \\
\hline \multirow[t]{3}{*}{192} & +9.02 & +2.19(Ø) & - & +0.94(Ø) & - & - & $-3.14(\mathrm{SB})$ & - \\
\hline & +9.18 & +3.43(Ø) & - & - & +3.16(Ø) & - & - & $-1.11(\mathrm{Sb})$ \\
\hline & +7.63 & +0.09 (Ø) & +0.09(Ø) & - & - & $-3.87(\mathrm{SB})$ & - & - \\
\hline \multirow[t]{2}{*}{226} & +9.84 & +1.70 (Ø) & - & +1.39(Ø) & - & - & $-3.66(\mathrm{SB})$ & - \\
\hline & +7.66 & +3.11(Ø) & - & - & $+2.88(\varnothing)$ & - & - & $-2.91(\mathrm{Sb})$ \\
\hline
\end{tabular}

b: bacteriostatic; B: bactericide; S: synergism; +: increase growth; -:decrease growth; Ø: no effect (Lorian 2005).

TABLE V

Log reduction of colony-forming unit (CFU)/mL of methicillin-resistant coagulase-negative Staphylococcus aureus isolates using the time-kill curve after incubation with vancomycin (VAN), sulfamethoxazole/trimethoprim (SXT), rifampin (RIF) and imipenem (IPM) alone and in combination with VAN in relation to the initial inoculum after $24 \mathrm{~h}$ of incubation on $37^{\circ} \mathrm{C}$

\begin{tabular}{|c|c|c|c|c|c|c|c|c|}
\hline \multirow[b]{2}{*}{ Strain } & \multicolumn{8}{|c|}{$\log$ CFU/mL } \\
\hline & Control & VAN & SXT & RIF & IPM & $\mathrm{VAN}+\mathrm{SXT}$ & $\mathrm{VAN}+\mathrm{RIF}$ & VAN + IPM \\
\hline & +9.43 & +4.25(Ø) & +0.79 (Ø) & - & - & +0.51 (SØ) & - & - \\
\hline \multirow[t]{3}{*}{155} & +9.53 & +5.79 (Ø) & - & +0.92(Ø) & - & - & $-2.54(\mathrm{Sb})$ & - \\
\hline & +1.37 & $+5.07(\varnothing)$ & - & - & +1.71(Ø) & - & - & $+1.39(\mathrm{~S} \varnothing)$ \\
\hline & +8.44 & +5.17 (Ø) & +1.55 (Ø) & - & - & +1.09 (SØ) & - & - \\
\hline \multirow[t]{4}{*}{253} & +10.67 & $+6.06(\varnothing)$ & - & +1.57 (Ø) & - & - & +1.23 (SØ) & - \\
\hline & +9.62 & +4.94(Ø) & - & - & +1.55 (Ø) & - & - & $-1.08(\mathrm{Sb})$ \\
\hline & \multicolumn{8}{|c|}{ Log CFU/mL (reapplication after $6 \mathrm{~h}$ of incubation) } \\
\hline & +9.26 & +1.78(Ø) & +1.81 (Ø) & - & - & $-2.99(\mathrm{SB})$ & - & - \\
\hline \multirow[t]{3}{*}{155} & +9.09 & +3.53(Ø) & - & $+0.37(\varnothing)$ & - & - & $-3.00(\mathrm{SB})$ & - \\
\hline & +10.45 & +3.30 (Ø) & - & - & +2.38(Ø) & - & - & $-0.84(\mathrm{Sb})$ \\
\hline & +9.79 & $-0.78(b)$ & +2.20(Ø) & - & - & -4.19 (SB) & - & - \\
\hline \multirow[t]{2}{*}{253} & +9.38 & +2.94(Ø) & - & +2.28 (Ø) & - & - & +0.35 (SØ) & - \\
\hline & +9.73 & +3.07 (Ø) & - & - & +0.78(Ø) & - & - & $-1.09(\mathrm{Sb})$ \\
\hline
\end{tabular}

b: bacteriostatic; B: bactericide; S: synergism; +: increase growth; -:decrease growth; Ø: no effect (Lorian 2005).

antimicrobials were applied in very dilute concentrations, especially for strains susceptible to RIF where the MIC for some of them was $0.002 \mu \mathrm{g} / \mathrm{mL}$. Therefore, the possibility that the real effect was synergistic, rather than additive, should not be ignored. Our results were similar to those from Yamaoka (2007) and Frame and McLaurin (1984), who demonstrated synergistic effects of the VAN + SXT and VAN + RIF combinations. 
The first author observed a synergistic effect of antimicrobial combinations by cell culture using a MRSA strain obtained from a patient with bacterial endocarditis and brain abscesses. The other authors reported the cure of four patients infected with MRSA and four with MRCNS treated with VAN plus SXT or RIF.

The VAN + IMP combination was evaluated by E-test strips and synergistic effects were observed on almost all strains (95.5\%), except for strain 193, a MRCNS which showed an additive effect with a FIC index of 0.6 , a value very close to the parameter set for synergistic effect $(\mathrm{FIC} \leq 0.5)$ (Table II). This result is in agreement with studies by Totsuka et al. (1999) and Kobayashi (2005), who showed synergism between VAN and IPM in $94 \%$ and $92 \%$ of the MRSA strains, respectively. In our study, MRSA strains with MIC $\geq$ $32 \mu \mathrm{g} / \mathrm{mL}$ for IPM when combined with $1 / 2$ MIC of VAN became susceptible to IPM with MIC values $\leq$ $0.4 \mu \mathrm{g} / \mathrm{mL}$ (Table II). Similarly, Rochon-Edouard et al. (2000) observed synergistic bactericidal effects of the VAN + IPM combination in sub-inhibitory concentrations using the checkerboard technique in $69 \%$ of the MRSA strains they tested.

We followed the criteria previously proposed for the determination of synergistic, additive, indifferent and antagonistic effects of antimicrobial drug combinations. In a time-kill curve experiment without antimicrobial reapplication, we observed that combinations of VAN + SXT and VAN + RIF were indifferent for most strains, if SXT and RIF are considered to be the most active antimicrobials. However, this assumption does not acknowledge the pharmacokinetic properties of these antimicrobials, since SXT and RIF are not often used individually to combat a systemic staphylococcal infection, due to their toxicity and rapid emergence of resistance (Yamaoka 2007). Therefore, we considered VAN to be the essential antimicrobial agent and determined its best partner. The time-kill curve experiment showed that all combinations were synergistic in relation to VAN alone, which at $1 / 2$ MIC, showed no effect against virtually all strains tested (Tables IV, V). For example, at $24 \mathrm{~h}$, the combination of VAN + SXT killed staphylococcal strains about four times more than VAN alone (Table III). Thus, after analysing the increase of the log reduction of the bacterial cell numbers after reapplication of SXT and RIF, we verified a concentration-dependent activity for these antimicrobials. However, VAN did not show an increase of log reduction on reapplication, demonstrating a non-concentration-dependent activity. This is a pharmacodynamic characteristic commonly related to these drugs (Brunton et al. 2006).

IPM is a carbapenem belonging to the $\beta$-lactams class that has excellent activity on Gram-negative bacteria, but has no effect on staphylococci resistant to methicillin (Brunton et al. 2006). In some Brazilian hospitals, IPM is combined with VAN as a therapy for systemic infections. This treatment is used to broaden the spectrum of action, especially in cases of unknown pathogens (negative blood cultures) or without laboratory results. Thus, VAN is effective against staphylococci resistant to methicillin, while IPM is effective against multidrug-resistant Gram-negative bacteria. For this reason, the VAN + IPM combination was introduced in our study. In both trials, the combination of $1 / 2 \mathrm{MIC}$ of VAN + 1/2 MIC of IPM was shown to be synergistic, with an average reduction of $5 \log \mathrm{CFU} / \mathrm{mL}$ for all four selected strains in relation to VAN alone after $24 \mathrm{~h}$ of incubation. These results are in agreement with other studies which showed the bactericidal activity of this combination after $24 \mathrm{~h}$ of incubation with MRSA strains, using the time-kill curve method (Totsuka et al. 1999, Rochon-Edouard et al. 2000, Jacqueline et al. 2005). There was no significant decrease in $\log$ CFU after antimicrobial reapplication, indicating a non-concentration-dependent activity previously described as a pharmacological propriety of $\beta$-lactam drugs (Brunton et al. 2006). Our kinetic analysis agreed with the results of the E-test method, confirming the efficacy of synergistic combinations and the accuracy of this technique. The VAN + IPM antimicrobial combination has promise for further in vivo studies.

According to Rybak et al. (2009), bacterial strains with a VAN MIC from 1.0-2.0 $\mu \mathrm{g} / \mathrm{mL}$ are related to therapeutic failure and emergence of resistance. In our study, we showed a synergistic effect of the antimicrobial combinations against strains with VAN MIC from 1.0-2.0 $\mu \mathrm{g} /$ $\mathrm{mL}$. In particular, our observation of an in vitro synergistic effect of VAN + IPM supports the possibility that this combination could also be synergistic in vivo. Further work in this area is urgently required, since VAN + IPM is already widely used in our country and may become established as a new therapeutic option, with additional pharmacokinetic and pharmacodynamic studies.

We tested combinations of VAN + SXT, VAN + RIF and VAN + IPM. The VAN + IPM combination especially showed synergistic action in sub-MIC concentrations, when analyzed by pharmacodynamic methods. More studies on antimicrobial combinations with VAN are necessary. Additional in vivo evidence could contribute to a reduction in the standard VAN dosage or treatment time. However, these aspects should first be well established in the clinic, particularly in regard to possible side effects and therapeutic failure. We hope that our research will lead to a new low-cost therapeutic option against multi-resistant staphylococci, one of the most important infectious agents within and outside the hospital.

\section{ACKNOWLEDGEMENTS}

To Eliezer Menezes Pereira, for his help with the antimicrobial preparations in the early stages of the project.

\section{REFERENCES}

Alou L, Cafini F, Sevillano D, Unzueta I, Prieto J 2004. In vitro activity of mupirocin and amoxicillin-clavulanate alone and in combination against staphylococci including those resistant to methicillin. Int J Antimicrob Agents 23: 513-516.

Brunton LL, Lazo JS, Parker KL 2006. Goodman \& Gilman's: the pharmacological basis of therapeutics, 11th ed., McGraw-Hill, New York, 1219 pp.

Christoffersen RE 2006. Antibiotics - an investment worth making? Nat Biotechnol 24: 1512-1514. 
CLSI - Clinical and Laboratory Standards Institute 2009. M07-A8 Methods for dilution antimicrobial susceptibility tests for bacteria that grow aerobically; approved standard, 18th ed., Wayne, Pennsylvania, $10 \mathrm{pp}$.

Dehority W 2010. Use of vancomycin in pediatrics. Pediatr Infect Dis J 29: 462-464.

Frame PT, McLaurin RL 1984. Treatment of CSF shunt infections with intrashunt plus oral antibiotic therapy. J Neurosurg 60: 354-360.

Hazlewood KA, Brouse SD, Pitcher WD, Hall RG 2010. Vancomycinassociated nephrotoxicity: grave concern or death by character assassination? Am J Med 123: e1-7.

Hidron AI, Edwards JR, Patel J, Horan TC, Sievert DM, Pollock DA, Fridkin SK, National Healthcare Safety Network Team; Participating National Healthcare Safety Network Facilities 2008. NHSN annual update: antimicrobial-resistant pathogens associated with healthcare-associated infections: annual summary of data reported to the National Healthcare Safety Network at the Centers for Disease Control and Prevention, 2006-2007. Infect Control Hosp Epidemiol 29: 996-1011.

Jacqueline C, Navas D, Batard E, Miegeville AF, Le Mabecque V, Kergueris MF, Bugnon D, Potel G, Caillon J 2005. In vitro and in vivo synergistic activities of linezolid combined with subinhibitory concentrations of imipenem against methicillin-resistant Staphylococcus aureus. Antimicrob Agents Chemother 49: 45-51.

Kobayashi Y 2005. Study of the synergism between carbapenems and vancomycin or teicoplanin against MRSA, focusing on S-4661, a carbapenem newly developed in Japan. J Infect Chemother 11: 259-261.

Lorian V 2005. Antibiotics in laboratory medicine, 5th ed., Lippincot Williams \& Wilkins, Philadelphia, 889 pp.

Miranda-Novales G, Leaños-Miranda BE, Vilchis-Pérez M, Solórzano-Santos F 2006. In vitro activity effects of combinations of cephalothin, dicloxacillin, imipenem, vancomycin and amikacin against methicillin-resistant Staphylococcus spp strains. Ann Clin Microbiol Antimicrob 5: 25.
Nguyen HM, Graber CJ 2010. Limitations of antibiotic options for invasive infections caused by methicillin-resistant Staphylococcus aureus: is combination therapy the answer? J Antimicrob Chemother 65: 24-36.

Pallotta KE, Manley HJ 2008. Vancomycin use in patients requiring hemodialysis: a literature review. Semin Dial 21: 63-70.

Rand KH, Houck HJ 2004. Synergy of daptomycin with oxacillin and other beta-lactams against methicillin-resistant Staphylococcus aureus. Antimicrob Agents Chemother 48: 2871-2875.

Rochon-Edouard S, Pestel-Caron M, Lemeland JF, Caron F 2000. In vitro synergistic effects of double and triple combinations of beta-lactams, vancomycin, and netilmicin against methicillinresistant Staphylococcus aureus strains. Antimicrob Agents Chemother 44: 3055-3060.

Rybak M, Lomaestro B, Rotschafer JC, Moellering R Jr, Craig W, Billeter M, Dalovisio JR, Levine DP 2009. Therapeutic monitoring of vancomycin in adult patients: a consensus review of the American Society of Health-System Pharmacists, the Infectious Disease Society of America, and the Society of Infectious Diseases Pharmacists. Am J Health Syst Pharm 66: 82-98.

Schuenck RP, Pereira EM, Iorio NL, Dos Santos KR 2008. Multiplex PCR assay to identify methicillin-resistant Staphylococcus haemolyticus. FEMS Immunol Med Microbiol 52: 431-435.

Sievert DM, Rudrik JT, Patel JB, McDonald LC, Wilkins MJ, Hageman JC 2008. Vancomycin-resistant Staphylococcus aureus in the United States, 2002-2006. Clin Infect Dis 46: 668-674.

Totsuka K, Shiseki M, Kikuchi K, Matsui Y 1999. Combined effects of vancomycin and imipenem against methicillin-resistant Staphylococcus aureus (MRSA) in vitro and in vivo. $J$ Antimicrob Chemother 44: 455-460.

Yamaoka T 2007. The bactericidal effects of anti-MRSA agents with rifampicin and sulfamethoxazole-trimethoprim against intracellular phagocytized MRSA. J Infect Chemother 13: 141-146. 